\title{
Poisoning in domestic cats in Brazil: toxicants, clinical signs, and therapeutic approaches
}

\author{
[Intoxicação em gatos domésticos no Brasil: toxicantes, sinais clínicos e \\ abordagens terapêuticas] \\ M.P.B. Jardim ${ }^{1}$, L.F. Farias ${ }^{1}$, G.C. Cid ${ }^{1}$, H.J.M. Souza ${ }^{2}$ \\ ${ }^{1}$ Aluno de pós-graduação - Universidade Federal Rural do Rio de Janeiro - Seropédica, RJ \\ ${ }^{2}$ Universidade Federal Rural do Rio de Janeiro - Seropédica, RJ
}

\begin{abstract}
This study evaluated the most common toxic agents affecting domestic cats, the clinical signs of toxicity, and the therapeutic approaches for recovery. A survey on poisoning in cats was conducted among small animal veterinary practitioners from 2017 to 2018 . Of the 748 completed questionnaires, $543(72.6 \%)$ were evaluated. Pesticides and household cleaning supplies were the most common causes of poisoning in cats. The toxicant groups included pesticides and household cleaning supplies (organophosphates), human drugs (acetaminophen), plants/plant derivatives (lily), and veterinary drugs (tramadol). The major clinical signs for these four groups of toxicants were (1) acetaminophen poisoning, which caused oxidative erythrocyte damage; (2) muscarinic and nicotinic cholinergic syndrome, which resulted from organophosphate poisoning; (3) acute kidney injury, which resulted from intoxication of lily; and (4) serotonin syndrome, which resulted from tramadol toxicosis. Interventions for treating poisoning in cats were based on the clinical presentation of animals. In the present study, the significant toxins identified to be dangerous for cats were characterized using the obtained data in Brazil as well as the main associated clinical signs and therapy recommended by veterinarians.
\end{abstract}

Keywords: poisoning, acetaminophen, organophosphate, lily, tramadol

\section{RESUMO}

Objetiva-se com este trabalho caracterizar os principais toxicantes para gatos domésticos, bem como os prevalentes sinais clínicos e a terapêutica associada. Uma pesquisa sobre envenenamento em gatos foi realizada entre médicos veterinários no período de 2017 a 2018. Dos 748 questionários preenchidos, 543 (72,6\%) foram avaliados. Pesticidas e domissanitários foram os principais causadores de intoxicação em gatos. Entre os grupos tóxicos, destacaram-se, na categoria pesticidas e domissanitários (organofosforados), medicamentos humanos (acetaminofeno), plantas e derivados de planta (lírio) $e$ medicamentos veterinários (tramadol). Os principais sinais clínicos para os quatro grupos de substâncias tóxicas foram: (1) intoxicação por acetaminofeno, que causou dano eritrocitário oxidativo; (2) síndrome colinérgica muscarínica e nicotínica, resultante do envenenamento por organofosforado; (3) lesão renal aguda, causada pela intoxicação por lírio; e (4) síndrome serotoninérgica, resultante da exposição ao tramadol. As intervenções realizadas para o tratamento dos envenenamentos foram justificáveis mediante a apresentação clínica dos animais. Por meio dos dados obtidos, puderam-se caracterizar os principais tóxicos para gatos no Brasil, bem como os principais sinais clínicos associados e a terapêutica preconizada pelos médicos veterinários.

Palavras-chave: envenenamento, acetaminofeno, organofosforado, lírio, tramadol

Recebido em 27 de fevereiro de 2020

Aceito em 8 de setembro de 2020

E-mail: jardim.marii@gmail.com 


\section{INTRODUCTION}

Intoxication is an impaired condition caused by the synergy of a toxic agent with a biological system (Nogueira, 2012). In humans and animals, this interaction can be potentially lethal. Domestic cats are popular pets who best fit the modern lifestyle. These animals have peculiarities specific to the species that may readily predispose them to poisoning. The susceptibility of their red blood cells to oxidative injuries and reduced liver capacity in certain metabolic processes, particularly those associated with a deficiency of the glucuronyl transferase family enzymes, are the primary characteristics that make domestic feline predisposed to harmful insults (Anjos and Brito, 2009; Court, 2013). Moreover, the behavioral characteristics of cats, such as intensive hunting, investigative behavior that leads to crawling underthings, and their habit of licking their fur, may lead to increased exposure to toxins (Grave and Boag, 2010).

According to the American Society for the Prevention of Cruelty to Animals, Animal Poison Control Center and the UK's Veterinary Poisons Information Service, cats commonly show toxicity following exposure to veterinary and human therapeutic agents, rodenticides, household cleaning supplies, pesticides, plants, food, heavy metals, and industrial products (Merola and Dunayer, 2006; Grave and Boag, 2010).

The exposure of cats to toxic substances and the consequent deleterious effects of this interaction create an unquestionable reality, thus representing topics that require constant exploration and updates because of the advent of new therapeutic options for the treatment of diseases and the changes in clinical behavior by veterinarians. Therefore, it is necessary to identify the primary toxic agents that endanger domestic cats and to understand the risk factors associated with poisoning to establish preventive alert measures via increased awareness among veterinarians. Therefore, the present study aimed to identify the most common toxic agents for domestic cats, the clinical signs of their toxicity, and the therapeutic approaches.

\section{MATERIALS AND METHODS}

Ethical approval was obtained from the Ethics Committee on Research (COMEP) of the Rural Federal University of Rio de Janeiro-UFRRJ (protocol number: 23083.030724/2017-67) attending the ethical concerns regarding human research established by the 466/12 Brazilian law. Questionnaires were distributed to small animal veterinary practitioners listed across the Brazilian territory (midwest, northeast, north, south, and southeast regions) from November 2017 to November 2018. The small animal veterinary practitioners were asked whether they had observed one or more cases of poisoning in cats throughout their careers. Both printed versions and web-based questionnaires were used for the survey. The Survey Monkey website (SurveyMonkey.com, LLC, Palo Alto, CA; www.surveymonkey.com) was used to administer the questionnaires electronically.

The selection of participants was performed using the convenience sampling method, by social media and personally. The Survey Monkey website was the most used tool for administration of questionnaires. In addition, small animal veterinary practitioners were recruited during national veterinary events and asked to complete printed versions of the questionnaire. Each region was represented by at least five veterinarians. Prior to initiating the survey, all the participating small animal veterinary practitioners were informed about the aims of the study and that all medical notes and data collected during the research were meant for academic purposes only and would not be nominally disclosed to third parties.

All small animal veterinary practitioners were asked to complete a survey for each case of intoxication in cats that they have assisted with throughout their careers. The questionnaire comprised 10 multiple choice questions ( 8 with an additional box for personal comments and 2 openended questions). The logic system was used for question number 4, i.e., depending on the responses of the small animal veterinary practitioners', they were further directed to a specific question number 10 (Figure 1). 


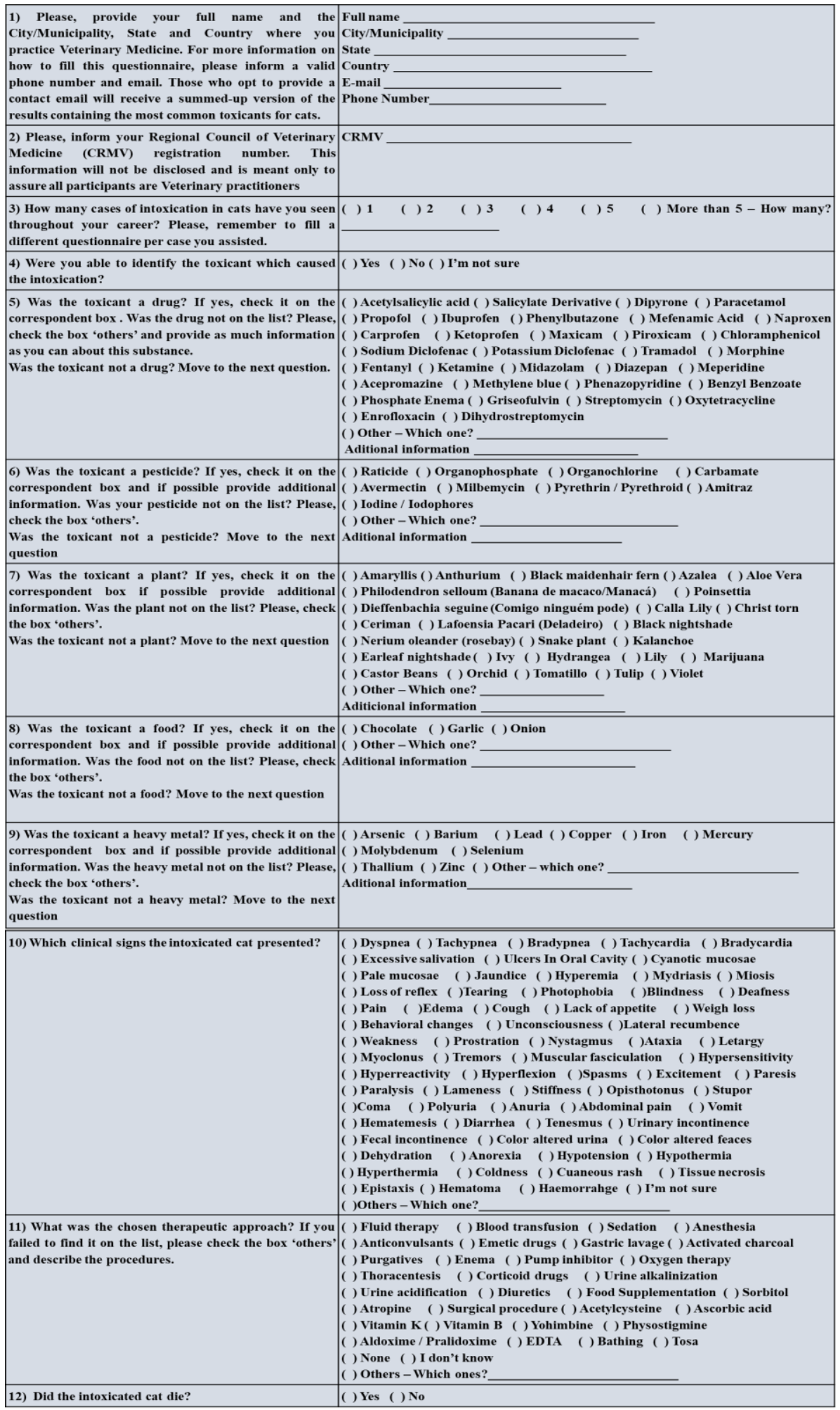

Figure 1. Questionnaire administered to small animal veterinary practitioners regarding intoxication in domestic cats from 2017 to 2018 
Regarding the inclusion criterion, questionnaires filled by small animal veterinary practitioners registered in the Brazilian Class Council (Regional Council of Veterinary Medicine; CRMV) were included. The exclusion criterion was inadequate or incomplete questionnaires. The responses were entered into a spreadsheet and open-ended questions were categorized into classes of common responses. All the questions were assigned absolute and relative (\%) values to evaluate whether the region was a risk factor for poisoning and the occurrence of a specific category of toxicants or whether the mortality rate depends on the class to which the toxicity belongs. The Fisher's exact test of independence was applied (simulation-based on 2000 replications) with 5\% significance. For such statistical analysis, the Excel spreadsheet editor was usedMicrosoft Office, 2013 and the statistical software R 3.5.2.

\section{RESULTS}

A total of 339 small animal veterinary practitioners completed 748 questionnaires; however, 205 questionnaires $(27.4 \%)$ failed to meet the inclusion criteria. Finally, 543 (72.6\%) questionnaires were assessable. Of these 543 questionnaires regarding cases of intoxication in cats, the respondents were able to identify the toxicant in $427(78.6 \%)$ cases. Overall, 88 $(16.2 \%)$ small animal veterinary practitioners were not sure of the toxicant, whereas $28(5.2 \%)$ failed to identify the cause of intoxication.

Pesticides and household cleaning supplies (44.0\%), human drugs (30.0\%), veterinary drugs $(10.7 \%)$, and plants/plant derivatives $(9.6 \%)$ were the most common toxicants for cats, whereas heavy metals and food products accounted for $<1 \%$ of the toxicants. The toxicant could not be identified in $5.2 \%$ cases (Table 1). Of the 543 questionnaires regarding cases of toxicity reported in this study, $393(72.4 \%)$ questionnaires reported cases in the southeast region of Brazil, $102(18.7 \%)$ in the southern region, $25(4.7 \%)$ in the northeast region, $14(2.6 \%)$ in the midwest region, and $9(1.6 \%)$ in the northern region (Table 1).

Pesticides and household cleaning supplies were the predominant xenobiotic toxins identified in the southeast region $(41.5 \%)$, southern region
$(52.9 \%)$, northeast region $(52.0 \%)$, and northern $(55.6 \%)$ region of Brazil. Most cases of intoxication in cats in the midwest region were mainly attributed to contact with human drugs $(57.2 \%)$. The Fisher's exact test of variance did not reveal any association between geographical location and the number of intoxicated cats affected by the toxins $(\mathrm{p}=0.071)$.

The most frequently reported toxicants identified were organophosphates in the pesticide and household cleaning supply class (56 cats; $10.3 \%$ ), acetaminophen in the human drug class (78 cats; $14.4 \%)$, tramadol in the veterinary drug class (17; $3.1 \%)$, and lily in the plant/plant derivative class (21 cats; $3.9 \%$ ). Food and heavy metal products were not addressed in this list because they did not represent a significant number of toxic substances in the study. The clinical signs associated with acetaminophen, organophosphates, lily, and tramadol intoxications are summarized in Table 2. The selected therapeutic approaches for treating toxicological emergencies due to acetaminophen, organophosphates, lily, and tramadol in cats are listed in Table 3.

The mortality rate in the total population of intoxicated cats was $21.4 \%$ (116 animals). The highest mortality rate was associated with the consumption of human drugs (45 cats; $27.6 \%$ ) and other toxic drugs of unknown origin ( 7 cats; $25 \%$ ). The mortality rate was $18.8 \%$ (45 cats) with pesticides and household cleaning supplies, $17.3 \%$ (9 cats) with plants and plant derivatives, and $15.5 \%$ (9 cats) with veterinary drugs. The mortality rate with heavy metal poisoning was $100 \%$ (which was biased due to the minute sample size) because only one case of such poising was reported, and that cat died. There were no deaths associated with food poisoning.

The association between the classes of toxic agents and the mortality rate was investigated using Fisher's exact test of variance and a $p$ value of 0.074 was obtained, demonstrating that the classes of toxic agents were not significant factors for the incidence of death. The human drugs class of toxicity accounted for the highest mortality rate and the highest incidence of lethality relativized was due to poisoning resulting from acetaminophen $(35.9 \%)$ Of the 339 respondents, $328(96.75 \%)$ provided their email IDs and received survey results in a compiled format. 
Poisoning in domestic...

Table 1. Intoxications in domestic cats from 2017 to 2018: toxicants and geographical distribution of reported cases

\begin{tabular}{|c|c|c|c|c|c|c|c|}
\hline \multirow{2}{*}{ Toxin/source toxins } & & \multicolumn{6}{|c|}{ Brazilian regions } \\
\hline & & Southeast & South & Northeast & North & Midwest & Total \\
\hline \multirow{4}{*}{ Food products } & $\mathrm{N}$ & 1 & 1 & 0 & 0 & 0 & 2 \\
\hline & $\%$ toxin & 50 & 50 & 0 & 0 & 0 & 100 \\
\hline & $\%$ area & 0.25 & 1.0 & 0 & 0 & 0 & \\
\hline & $\%$ total & 0.2 & 0.2 & 0 & 0 & 0 & 0.4 \\
\hline \multirow{4}{*}{ Human drugs } & $\mathrm{N}$ & 112 & 31 & 8 & 4 & 8 & 163 \\
\hline & $\%$ toxin & 68.7 & 19.0 & 4.9 & 2.5 & 4.9 & 100 \\
\hline & $\%$ area & 28.5 & 30.4 & 32.0 & 4.4 & 57.2 & \\
\hline & $\%$ total & 20.6 & 5.7 & 1.5 & 0.7 & 1.5 & 30.0 \\
\hline \multirow{4}{*}{ Heavy metal } & $\mathrm{N}$ & 1 & 0 & 0 & 0 & 0 & 1 \\
\hline & $\%$ toxin & 100 & 0 & 0 & 0 & 0 & 100 \\
\hline & $\%$ area & 0.25 & 0 & 0 & 0 & 0 & \\
\hline & $\%$ total & 0.2 & 0 & 0 & 0 & 0 & 0.2 \\
\hline \multirow{4}{*}{$\begin{array}{l}\text { Pesticides and household } \\
\text { cleaning supplies }\end{array}$} & $\mathrm{N}$ & 163 & 54 & 13 & 5 & 4 & 239 \\
\hline & $\%$ toxin & 68.2 & 22.6 & 5.4 & 2.1 & 1.7 & 100 \\
\hline & $\%$ area & 41.5 & 52.9 & 52.0 & 55.6 & 28.6 & \\
\hline & $\%$ total & 30.0 & 9.9 & 2.4 & 0.9 & 0.7 & 44.0 \\
\hline \multirow{4}{*}{ Plants and plants derivatives } & $\mathrm{N}$ & 48 & 4 & 0 & 0 & 0 & 52 \\
\hline & $\%$ toxin & 92.3 & 7.7 & 0 & 0 & 0 & 100 \\
\hline & $\%$ area & 12.2 & 3.9 & 0 & 0 & 0 & \\
\hline & $\%$ total & 8.8 & 0.7 & 0 & 0 & 0 & 9.6 \\
\hline \multirow{4}{*}{ Veterinary drugs } & $\mathrm{N}$ & 48 & 6 & 3 & 0 & 1 & 58 \\
\hline & $\%$ toxin & 82.8 & 10.3 & 5.2 & 0 & 1.7 & 100 \\
\hline & $\%$ area & 12.2 & 5.9 & 12.0 & 0 & 7.1 & \\
\hline & $\%$ total & 8.8 & 1.1 & 0.6 & 0 & 0.2 & 10.7 \\
\hline \multirow{4}{*}{ Unknown } & $\mathrm{N}$ & 20 & 6 & 1 & 0 & 1 & 28 \\
\hline & $\%$ toxin & 71.4 & 21.4 & 3.6 & 0 & 3.6 & 100 \\
\hline & $\%$ area & 5.1 & 5.9 & 4.0 & 0 & 7.1 & \\
\hline & $\%$ total & 3.7 & 1.1 & 0.2 & 0 & 0.2 & 5.2 \\
\hline \multirow{2}{*}{ Total } & $\mathrm{N}$ total & 393 & 102 & 25 & 9 & 14 & 543 \\
\hline & $\%$ total & 72.4 & 18.7 & 4.7 & 1.6 & 2.6 & 100 \\
\hline
\end{tabular}

Table 2. Intoxications in domestic cats from 2017 to 2018: correlation between clinical signs and toxicants

\begin{tabular}{llc}
\hline \multicolumn{1}{c}{ Toxicants } & Clinical signs & Frequency (\%) \\
\hline \multirow{2}{*}{ Acetaminofen (78 cases) } & Excessive salivation & $31(7.1)$ \\
& Cyanotic mucosa & $27(6.2)$ \\
& Dyspnea & $22(5.0)$ \\
& Excessive salivation & $34(8.8)$ \\
Organophosphates (56 cases) & Muscular fasciculation & $19(4.9)$ \\
& Disorientation & $18(4.6)$ \\
& Vomiting & $18(4.6)$ \\
Lilly (21 cases) & Dehydration & $6(8.0)$ \\
& Vomiting & $6(8.0)$ \\
& Prostration & $6(8.0)$ \\
Tramadol (17 cases) & & \\
& Mydriasis & $9(14.3)$ \\
& Excessive salivation & $6(9.5)$ \\
\hline
\end{tabular}


Table 3. Intoxications in domestic cats from 2017 to 2018: correlation between therapeutic approaches and xenobiotic compounds

\begin{tabular}{|c|c|c|}
\hline Toxicants & Therapeutic approach & Frequency $(\%)$ \\
\hline \multirow{4}{*}{ Acetaminofen (78 cases) } & Fluid therapy & $56(24.0)$ \\
\hline & Acetylcysteine administration & $36(15.5)$ \\
\hline & Oxygen therapy & $25(10.7)$ \\
\hline & Gastric protector administration & $23(9.9)$ \\
\hline \multirow{4}{*}{ Organophosphates (56 cases) } & Fluid therapy & $38(19.2)$ \\
\hline & Atropine & $31(15.7)$ \\
\hline & Activated charcoal & $23(11.6)$ \\
\hline & Gastric protectors & $16(8.1)$ \\
\hline \multirow{4}{*}{ Lilly (21 cases) } & Fluid therapy & $15(39.5)$ \\
\hline & Food supplementation & $3(7.9)$ \\
\hline & Gastric protectors & $3(7.9)$ \\
\hline & Emetic drugs & $3(7.9)$ \\
\hline \multirow{2}{*}{ Tramadol (17 cases) } & Fluid therapy & $7(41.2)$ \\
\hline & None & $2(11.8)$ \\
\hline
\end{tabular}

\section{DISCUSSION}

The Survey Monkey tool provides an application for the development of effective online surveys. This platform is currently utilized for research associated with both human and animal medicine (Wilson et al., 2016; Raphael et al., 2018). Surveys via questionnaires have been effective for obtaining data on cat poisoning (Malik et al., 2010; Slater and Gwaltney-Brant, 2011). The class that accounted for the most cases of intoxicated domestic cats in the present study was the pesticides and household cleaning supply class, and this result was similar to that reported by Grave and Boag (2010) from the United Kingdom.

The highest incidence of intoxication in cats due to this class of agents is attributed to the toxic substances included in this group (organophosphates, rodenticides, carbamates, and other xenobiotics such as pyrethrins or pyrethroids) (Kohn et al., 2003; Malik et al., 2010; Henrique and Carneiro, 2014) to which cats are commonly exposed accidentally/ unintentionally. The region with the highest number of reported cases of intoxicated felines was the southeast region, which was corroborated by the fact that poisoning occurred predominantly in the more industrialized and populated places (Bille et al., 2016). Although such heterogeneity may have been due to the greater dissemination of the questionnaire to veterinarians close to the researchers of the present study who live and work in the southeast region.
In Brazil, only three studies evaluated the casuistry of intoxication in domestic cats, one carried out in the southeastern region, where there was a higher occurrence of cats intoxicated by medications for human use and the other two in the south, where pesticides and household cleaning products were predominant as toxicants (Barni et al., 2012; Medeiros et al., 2009; Zang et al., 2018). In the current study, in all regions of Brazil, with the exception of the Midwest, the main class of pesticides and household cleaning agents was found to be the main toxicant, which is similar to the two studies carried out in southern Brazil and is different from the research carried out in the Southeast of the country, it is noteworthy that the comparison with these other authors is hampered by the low sample number of cats evaluated, since they were studies involving not only the feline species but also dogs.

Acetaminophen is reportedly the most toxic human drug for cats (Webb et al., 2003; Mahdi and Van de Merwe, 2013) and is responsible for one of the 10 primary toxicoses identified in this species (Merola and Dunayer, 2006). According to national surveys, the possibility of accidental poisoning in cats with acetaminophen in Brazil was three times higher than that in European countries (Grave and Boag, 2010; Zang et al., 2018). Thus, the higher occurrence of acetaminophen-intoxicated cats at a national level could be due of the greater unfamiliarity about the toxic potential of this analgesic by cat owners, given that acetaminophen's poisoning is usually caused by owners who administer the drug to felines and are unaware of its toxicity (Allen, 
2003; Grave and Boag, 2010). Therefore, education and awareness concerning this drug is particularly important among the owners.

The most frequent clinical signs in cats with acetaminophen toxicosis were excessive salivation, cyanosis, and dyspnea, which are associated with the substance's potential to cause oxidative erythrocyte damage by p-aminophenol action and the deficiency of the glucuronyl transferase family of enzymes (Richardson, 2000; Allen, 2003; Merola and Dunayer 2006; Grave and Boag, 2010; Court, 2013). Therapeutic approaches for acetaminophen-intoxicated cats included fluid therapy, acetylcysteine administration, gastric mucosa protector administration, and oxygen therapy. Fluid therapy is utilized as a standard supportive therapy, whereas acetylcysteine administration and oxygen therapy are indicated to prevent oxidative injury and methemoglobinemia, respectively.

Oxidative erythrocyte damage was shown to be among the main clinical signs in acetaminophen poisoning; therefore, blood transfusion should have been prevalent among therapeutic approaches, given the need for this intervention in animals with clinical signs associated with the presence of methemoglobinemia. Moreover, most respondents did not use activated charcoal; however, this compound should always be administered even in late intoxication episodes because of the enterohepatic recirculation chelates of acetaminophen (Richardson, 2000; Webb et al., 2003; Merola and Dunayer 2006; Curti et al., 2009; Avizeh et al., 2010; Grave and Boag, 2010).

Organophosphates were identified as the predominant toxic xenobiotics in the pesticide and household cleaning supply class that poison cats; these poisonings possibly occurred due to its high toxicity, ease of purchasing products containing organophosphates (registered for agricultural, veterinary, or domestic use), and the poor supervision of the marketing of pesticides despite the fact that their use is prohibited or restricted (Xavier et al., 2007). Organophosphate toxicosis initially causes muscarinic cholinergic syndrome and subsequently causes nicotinic cholinergic syndrome, which results in the cats presenting excessive salivation, muscular fasciculation, disorientation, and vomiting, which is similar to that reported in our survey (Melo et al., 2002; Xavier et al., 2007; Henrique and Carneiro, 2014).
Fluid therapy and atropine, activated charcoal, and gastric protector administration were the primary treatment options recommended for organophosphate-intoxicated cats. Atropine was used for treating organophosphate toxicosis with an antagonistic purpose for the muscarinic effects caused; however, activated charcoal was also important because of the adsorbing function in this type of poisoning. Fluid therapy is a part of supportive therapy for treating such toxic injuries (Melo et al., 2002; Merola and Dunayer 2006; Xavier et al., 2007; Curti et al., 2009).

Oximes are potent reactivators of enzymatic activity and are considered as antidotes to organophosphate poisoning. The use of oximes was not particularly often in the present study probably because of the difficulty in its acquisition and the potential risk of clinical worsening of the condition of the animals due to the similarity of symptoms for the two clinical manifestations, organophosphate/carbamate toxicosis, and the contraindication of aldoxime when the cat was intoxicated by the latter (Xavier et al., 2007).

Lily was identified as the predominant toxic agent in the plant/plant derivative class by predominant casuistic; however, such a plant is one of the five main toxic xenobiotics for felines presumably because all the parts of this plant could be toxic to cats, and the lily plant owners lacked knowledge and awareness regarding its toxicity and danger (Merola and Dunayer 2006; Fitzgerald, 2010; Grave and Boag, 2010; Slater and GwaltneyBrant, 2011). The main clinical manifestations associated with lily toxicosis were dehydration, vomiting, and prostration, which were mainly related to gastrointestinal irritation and renal insult caused by the plant, although the precise mechanism of toxicity has not been elucidated (Merola and Dunayer, 2006; Berg et al., 2007; Fitzgerald, 2010; Grave and Boag, 2010; Slater and Gwaltney-Brant, 2011; Panziera et al., 2019).

The respondents opted for fluid therapy, food supplementation, gastric protector administration, and emetic drug administration for treating lily toxicosis. The preconized treatment for lily toxicosis includes immediate gastrointestinal decontamination. Intravenous fluid therapy has been indicated with a replacement electrolyte solution that should be used to correct hypovolemia and dehydration and maintain 
diuresis. Once renal failure develops, treatment is based on symptomatic and supportive care. The use of diuretics and hemodialysis was indicated in oliguric or anuric patients, although it may not have been highlighted because the intoxicated cats did not exhibit the advanced renal impairment required to justify such use (Merola and Dunayer, 2006; Berg et al., 2007; Fitzgerald, 2010; Grave and Boag, 2010; Bennet and Reineike, 2013).

Tramadol was identified as the predominant drug in the veterinary drug class that most often intoxicated cats in the present study. Accidental poisoning with tramadol usually occurs due to overdosage resulting from veterinary prescription errors, given that this opioid was once considered safe for cats (Indrawirawan and McAless, 2014). The number of tramadol-intoxicated cats in the present study was concerning and may reflect the misuse of the drug by professionals or the incorrect/improper use by owners. In the present study, tramadol intoxication resulted in mydriasis, excessive salivation, and behavioral changes, and serotonergic signs were commonly associated with this drug (KuKanich, 2013; Indrawirawan and McAless, 2014).

Most small animal veterinary practitioners administered fluid therapy to tramadolintoxicated cats. Ongoing supportive care as an intravenous fluid therapy is a useful tool to maintain adequate perfusion. Activated charcoal is also recommended for tramadol toxicity to adsorb intestinal metabolites even in the late stages of poisoning; Indrawirawan and McAless, 2014). Acetaminophen was identified as the predominant drug in the human drug class, accounting for the highest mortality rate according to our questionnaires. Barni et al. (2012) have reported similar results in a national survey. However, the mortality rate associated with acetaminophen poisoning in cats in the United Kingdom, as reported in this previous study, was nine times lower than that reported in the present study. Once early and aggressive supportive care is the cornerstone of stabilization in severely affected patients, it is believed that the owner's delay in seeking professional help and the inexperience of veterinary practitioners in managing cat toxicological emergencies may be contributing to the number of deaths (Richardson, 2000; Grave and Boag, 2010).

\section{CONCLUSIONS}

Pesticides and household cleaning supplies were the most common toxicants for cats in Brazil. Acetaminophen, organophosphates, lily, and tramadol were the most likely sources of intoxication for domestic felines. As for the clinical signs, oxidative stress (caused by acetaminophen), muscarinic and nicotinic cholinergic syndrome (derived from poisoning by organophosphates), gastrointestinal irritation and kidney injury (by contact with lily), and serotonin toxicity (due to exposure tramadol) were reported. Interventions for the treatment of poisonings were based on the clinical presentation of the animals, although it was noteworthy that there were appropriate procedures in each case that were not performed by the small animal veterinary practitioners. This fact is concerning and deserves attention, as it can contribute to a higher mortality rate of intoxicated felines that receive veterinary care. Education and awareness among the owners and small animal veterinary practitioners regarding prevention and proper therapies could reduce future occurrences and mortality resulting from toxicity in domestic cats.

\section{REFERENCES}

ALLEN, A.L. The diagnosis of acetaminophen toxicosis in a cat. Can. Vet. J., v.44, p.509-510, 2003.

ANJOS T.M.; BRITO H.F.V. Terapêutica felina: diferenças farmacológicas e fisiológicas. Medvep Rev. Cient. Med. Vet. Pequenos Anim. Anim. Estimação, v.7, p.554-567, 2009.

AVIZEH, R.; NAJAFZADEH, H.; RAZIJALALI, M.; SHIRALI, S. Evaluation of prophylactic and therapeutic effects of silymarin and $\mathrm{N}$-acetylcysteine in acetaminophen-induced hepatotoxicity in cats. J. Vet. Pharmacol. Ther., v.33, p.95-99, 2010.

BARNI, B.S.; VIDOR, S.B.; MÖRSCHBÄCHER P.D.; CONTESINI, E.A. Estudo retrospectivo dos casos de óbito por intoxicação em cães e gatos no Hospital de Clínicas Veterinárias da Universidade Federal do Rio Grande do Sul. In: SIMPÓSIO INTERNACIONAL DE EMERGÊNCIAS EM PEQUENOS ANIMAIS, 40., 2012, Porto Alegre. Anais... Porto Alegre: [s.n.], 2012. p.9. (Abstract).

BENNETT, A.J.; REINEKE, E.L. Outcome following gastrointestinal tract decontamination and intravenous fluid diuresis in cats with known lily ingestion: 25 cases (2001-2010). J. Am. Vet. Med. Assoc., v.242, p.11101116,2013 
BERG, R.I.M.; FRANCEY, T.; SEGEV, G. Resolution of acute kidney injury in a cat after lily (Lilium lancifolium) intoxication. J. Vet. Intern. Med., v.21, p.857-859, 2007.

BILlE, L.; TOSON, M.; MULATTI, P. et al. Epidemiology of animal poisoning: an overview on the features and spatio-temporal distribution of the phenomenon in the north-eastern Italian regions. Forensic Sci. Int., v.266, p.440-448, 2016.

COURT, M.H. Feline drug me tableolism and disposition: pharmacokinetic evidence for species differences and molecular mechanisms. Vet. Clin. N. Am. Small Anim. Pract., v.43, p.1039-1054, 2013.

CURTI, R.; KUPPER, J.; KUPFERSCHMIDT, H.; NAEGELI, H. Von hanf bis schokolade: tiervergiftungen im wandel der zeit eine retrospektive aufarbeitung der kasuistik des schweizerischen toxikologischen informationszentrums (1997 - 2006). Schweiz. Arch. Tierheilk., v.151, p.265-273, 2009.

FITZGERALD, K.T. Lily toxicity in the cat. Top. Companion Anim. Med., v.25, p.213-217, 2010.

GRAVE, T.W.; BOAG, A.K. Feline toxicological emergencies: when to suspect and what to do. J. Feline Med. Surg., v.12, p.849-860, 2010.

HENRIQUE, F.V.; CARNEIRO, R.S. Síndrome neuropática motora por inibidor de acetilcolinesterase em felinos: relato de quatro casos. Medvep Rev. Cient. Med. Vet. Pequenos Anim. Anim. Estimação, v.12, p.190-194, 2014.

INDRAWIRAWAN, Y.; MCALEES, T. Tramadol toxicity in a cat: case report and literature review of serotonin syndrome. J. Feline Med. Surg., v.16, p.572578, 2014.

KOHN, B.; WEINGART, C.; GIGER U. Haemorrhage in seven cats with suspected anticoagulant rodenticide intoxication. J. Feline Med. Surg., v.5, p.295-304, 2003.

KUKANICH, B. Outpatient oral analgesics in dogs and cats beyond nonsteroidal anti-inflammatory drugs: an evidence-based approach. Vet. Clin. N. Am. Small Anim. Pract., v.43, p.1109-1025, 2013.

MAHDI, A.; VAN DE MERWE D. Dog and cat exposures to hazardous substances reported to the Kansas State Veterinary Diagnostic Laboratory: 20092012. J. Med. Toxicol., v.9, p.207-2011, 2013.

MALIK, R.; WARD, M.P.; SEAVERS, A. et al. Permethrin spot-on intoxication of cats Literature review and survey of veterinary practitioners in Australia. J. Feline Med. Surg., v.12, p.5-14, 2010.
MEDEIROS, R.J.; MONTEIRO, F.O.; SILVA, G.C.; NASCIMENTO JÚNIOR, A. Casos de intoxicações exógenas em cães e gatos atendidos na Faculdade de Veterinária da Universidade Federal Fluminense durante o período de 2002 a 2008. Ciênc. Rural, 39, p.2105-2110, 2009.

MELO, M.M.; OLIVEIRA, N.J.F.; LAGO, L.A. Intoxicações causadas por pesticidas em cães e gatos. Parte I: Organoclorados, organofosforados, carbamatos e piretróides. Rev. Educ. Contin. CRMV-SP, v.5, p.188195, 2002

MEROLA V.; DUNAYER E. The 10 most common toxicoses in cats. Vet. Med., v.101, p.339-342, 2006.

NOGUEIRA, R.M.B. Toxicocinética e toxicodinâmica. In: NOGUEIRA, R.M.B.; ANDRADE, S.F. (Eds.). Manual de toxicologia veterinária. São Paulo: Roca, 2012. p.2-7.

PANZIERA, W.; SCHWERTZ, CI.; HENKER, L.C. et al. Lily poisoning in domestic cats. Acta Sci. Vet., v.47, p.1-5, 2019.

RAPHAEL, S.L.; FOSTER PAGE, L.A.; HOPCRAFT, M.S. et al. A survey of cariology teaching in Australia and New Zealand. BMC Med. Educ., v.18, p.1-9, 2018.

RICHARDSON, J.A. Management of acetaminophen and ibuprofen toxicoses in dogs and cats. J. Vet. Emerg. Crit. Care, v.10, p.285-291, 2000.

SLATER, M.R.; GWALTNEY-BRANT, S. Exposure circumstances and outcomes of 48 households with 57 cats exposed to toxic lily species. J. Am. Anim. Hosp. Assoc., v.47, p.386-390, 2011.

WEBB, C.B.; TWEDT, D.C.; FETTMAN, M.J.; MASON, G. S-adenosylmethionine (SAMe) in a feline acetaminophen model of oxidative injury. J. Feline Med. Surg., v.5, p.69-75, 2003.

WILSON, C.; BAIN, M.; DEPORTER, T. et al. Owner observations regarding cat scratching behavior: an internet-based survey. J. Feline Med. Surg., v.18, p.791-791, 2016.

XAVIER, F.G.; RIGHI, D.A.; SPINOSA, H.S. Toxicologia do praguicida aldicarb ("chumbinho"): aspectos gerais, clínicos e terapêuticos em cães e gatos. Ciênc. Rural, v.37, p.1206-1211, 2007.

ZANG, L.; BING, R.S.; ARAUJO, A.C.P.; FERREIRA, M.P. Retrospective study of small animal poisoning at the Veterinary Medical Teaching Hospital from South Region of Brazil. Acta Sci. Vet., v.46, p.17, 2018. 